\title{
Invertebrates living in polluted environments are potential source of novel anticancer agents
}

\author{
Morhanavallee SOOPRAMANIEN 1 (D), Mohammad Ridwane MUNGROO 1 (D), \\ Kuppusamy A. SAGATHEVAN 1 (D), Naveed Ahmed KHAN * 1 (D), Ruqaiyyah SIDDIQUI 2 (iD
}

1 Department of Biology, Chemistry and Environmental Sciences, College of Arts and Sciences, American University of Sharjah, University City, Sharjah, United Arab Emirates, 26666.

2 Department of Biology, Chemistry and Environmental Sciences, College of Arts and Sciences, American University of Sharjah, University City, Sharjah, United Arab Emirates, 26666.

* Corresponding Author. E-mail: naveed5438@gmail.com (N.A.K.); Tel. +971-50-315-1148.

Received: 16 January 2019 / Revised: 13 June 2019 / Accepted: 20 June 2019

\begin{abstract}
One of the leading causes of mortality and morbidity worldwide, cancer is a major medical concern with 14.1 and 8.2 million cases of new cancer cases and death cases recorded in 2012 alone. The number of deaths related to cancer are still on the rise despite various treatment options. Hence, there is a need for the identification of anticancer agents for treatment. This study focused on identifying anticancer agents from invertebrates thriving in polluted environments; Acheta domesticus (cricket), Anadara granosa (blood clam), Blaptica dubia (cockroach), Penaeus monodon (tiger prawn) and Scolpendra subspinipes (centipede) respectively. We hypothesized that gut microbes of animals/pests living in polluted environments such as cockroaches are a potential source of novel anticancer agents. To evaluate this hypothesis, invertebrates were dissected and their gut bacteria were identified and conditioned media were prepared. The conditioned media were used to conduct cytotoxicity assays, cell survival assays and cell growth assays, against two cancer cell lines (cervical and prostate cancer cells) as well as normal cells (HaCaT, aneuploid immortal keratinocyte). The results revealed that conditioned media from tiger prawn (Pseudomonas oryzihabitans) and centipede (Kocuria varians) exhibited significant cytotoxic and growth inhibitory effect against the cell lines tested. However, further studies need to be conducted to identify and characterize the active molecule(s).
\end{abstract}

KEYWORDS: Insects; pests; cancer; treatment; cytotoxicity; growth inhibition.

\section{INTRODUCTION}

Despite therapeutic advances and supportive care, cancer remains the leading cause of morbidity and mortality worldwide. According to the International Agency for Research on Cancer (IARC), there were 14.1 million new cancer cases, 32.6 million pre-existing cancer patients and 8.2 million deaths worldwide in 2012 alone [1,2]. By 2030, the global cancer burden is expected to nearly double, growing to 21.4 million cases and 13.2 million deaths. These numbers have remained significant in spite of available treatments for cancer including chemotherapy, radiation therapy, stem cell therapy, immunotherapy, targeted therapy, hormone therapy and surgery, highlighting the need to identify novel anticancer agent(s) [3-5].

Cancer is often linked to environmental pollutants, chemicals, infectious agents, genetics, hormones and radiation. With this in mind, it is important to note that pests, such as cockroaches can tolerate high levels of radiation, and thrive in unhygienic conditions with exposure to heavy metals. Other animals, such as crocodiles thrive from feeding on germ-infested rodents, exposed to heavy metals such as arsenic, cadmium, cobalt, chromium, mercury, nickel, lead, selenium, endure high levels of radiation, are among the very few species to survive the catastrophic Cretaceous-Tertiary extinction event, and yet live up to a 100 years [6-11]. Thus, it is reasonable to hypothesize that species such as crocodiles and cockroaches have developed mechanisms to defend themselves from noxious agents. We recently tested this hypothesis using an adult crocodile and showed that the organ lysates and sera of crocodile exhibited potent anticancer properties $[12,13]$. There are two logical reasons to explain these findings: (i) animals/pests living in polluted environments have evolved a strong immune system to counter cancer development, and/or, (ii) gut bacteria of animals/pests living in polluted environments produce anticancer molecule(s). In the present study, we selected several invertebrate species including Acheta domesticus, Anadara granosa, Blaptica dubia, Penaeus

How to cite this article: Soopramanien M, Mungroo MR, Sagathevan KA, Khan NA, Siddıqui R. Invertebrates living in polluted environments are potential source of novel anticancer agents. J Res Pharm. 2019; 23(6): 1079-1089. 
monodon and Scolpendra subspinipes, (Table 1) and tested their body lysates (Fig. 1) as well as their gut bacteria for potential anticancer properties.

Table 1. The species, scientific classification, habitat and diet of animals used in this study.

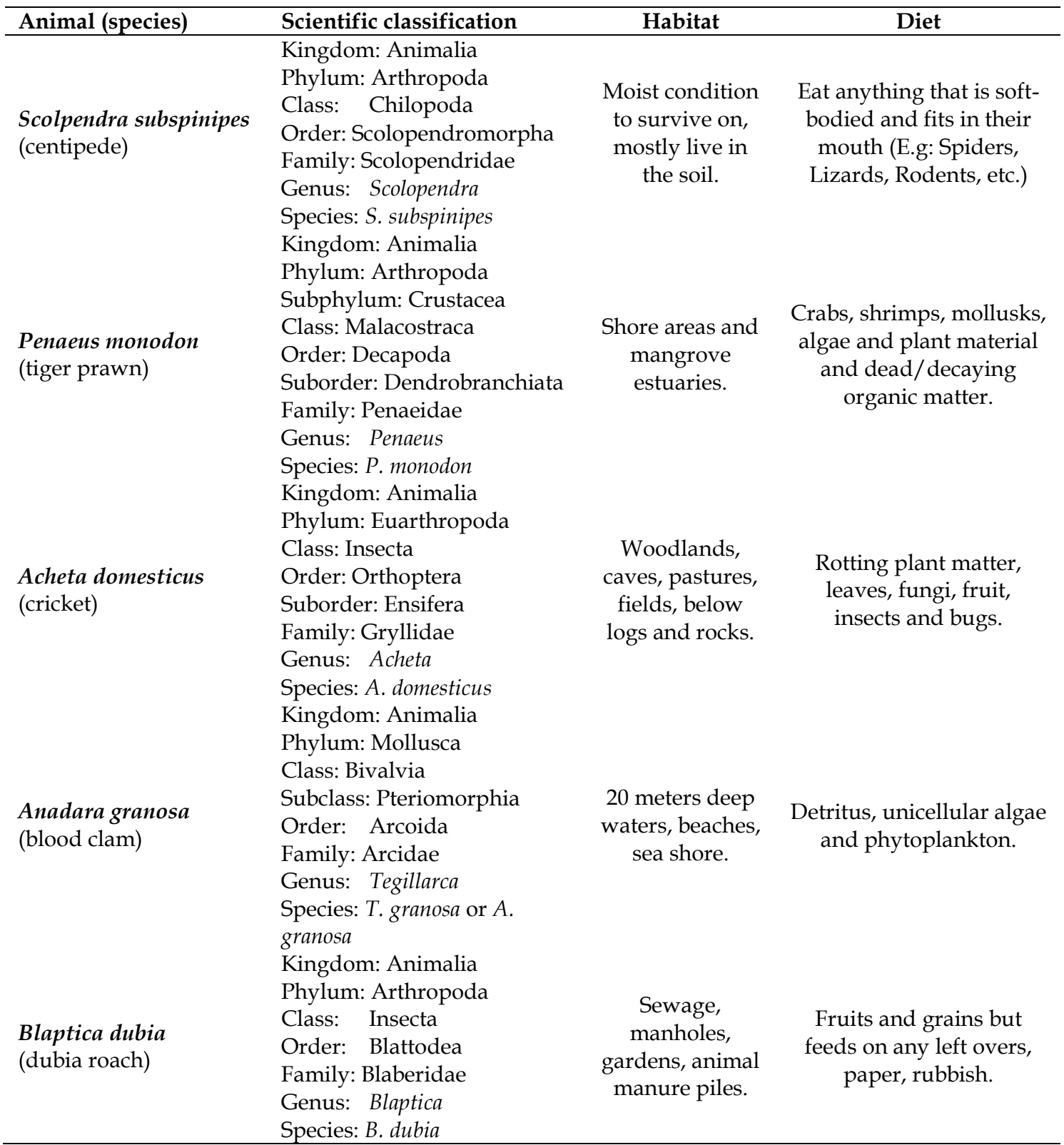

\section{RESULTS}

\subsection{A spectrum of bacteria was identified from cricket, blood clam, dubia roach, prawn and centipede}

A spectrum of bacteria was isolated from the gut of the various dissected invertebrates (Table 2).

The bacterial species isolated from cricket were Klebsiella pneumoniae, Pantoea sp., Staphylococcus lentus and Staphylococcus xylosus. While, Micrococus spp., Pseudomonas oryzihabitans and Staphylococcus sciuri were isolated from the gut of blood clam. The bacteria isolated from dubia roach include Staphylococcus hominis and Staphylococcus xylosus. Acinetobacter baumannii, Pseudomonas luteola, Pseudomonas oryzihabitans and Staphylococcus xylosus were isolated from tiger prawn. K. varians, Micrococcus spp., and Staphylococcus lentus were isolated from centipede. 


\subsection{Gut bacteria from selected invertebrates exhibited anticancer properties}

From above, bacterial conditioned media were tested for anticancer properties using normal and cancer cell lines. The results revealed that gut bacteria isolated from cockroaches showed anticancer effects (Table 3). For example, conditioned media of $S$. xylosus from cockroach gut showed reduced growth against PC3 cells compared with HaCat cells $(\mathrm{P}<0.05)$ (Table 3). However, conditioned media of $S$. xylosus showed no effects against Hela cells $(\mathrm{P}>0.05)$ (Table 3$)$.
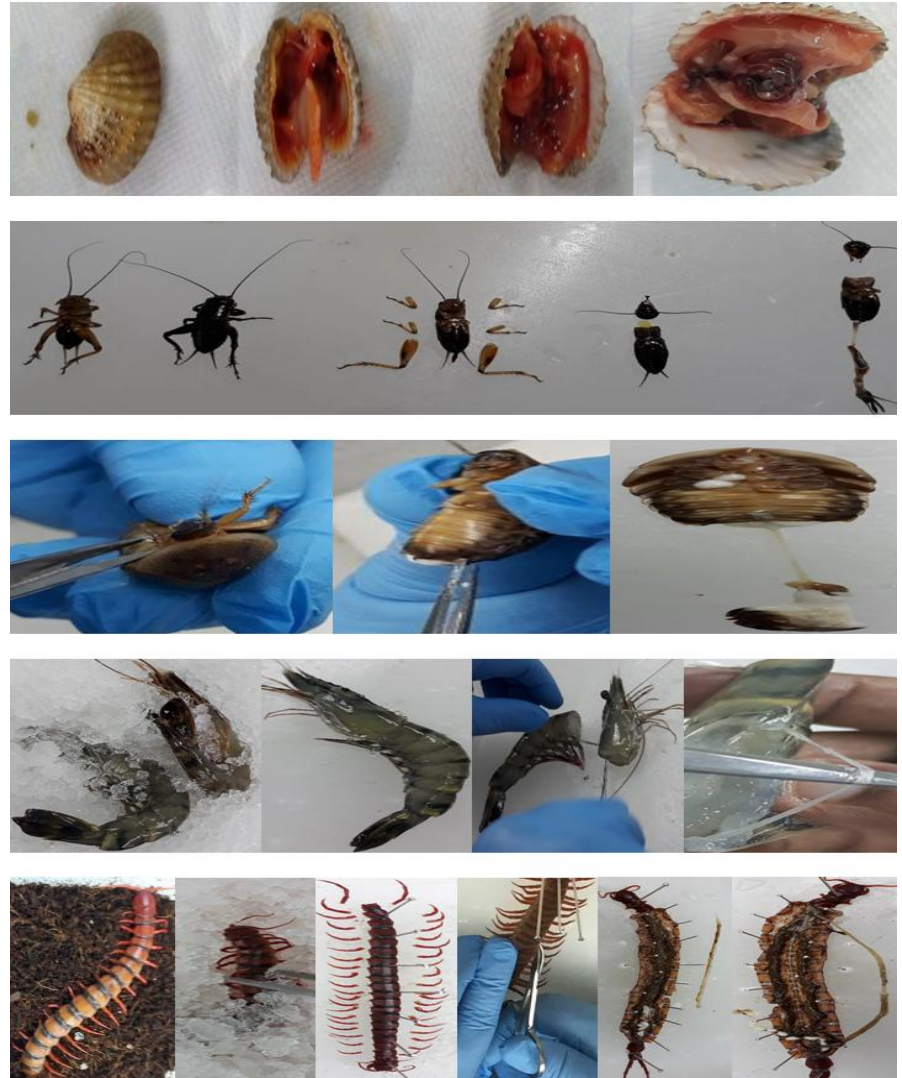

Figure 1. The dissection procedures conducted for the vertebrates used. A: Anadara granosa, B: Acheta domesticus, C: Blaptica dubia, D: Penaeus monodon and E: Scolpendra subspinipes.

Table 2. Bacteria isolated from selected invertebrates and their conditioned media.

\begin{tabular}{|c|c|c|}
\hline Species & Conditioned media & Bacterial Identity \\
\hline \multirow{3}{*}{$\begin{array}{l}\text { Scolpendra subspinipes } \\
\text { (centipede) }\end{array}$} & $\mathrm{CM} 1$ & Kocuria varians \\
\hline & CM2 & Micrococcus spp \\
\hline & $\mathrm{CM} 3$ & Staphylococcus lentus \\
\hline \multirow{4}{*}{$\begin{array}{l}\text { Penaeus monodon } \\
\text { (tiger prawn) }\end{array}$} & CM1 & Acinetobacter baumannii \\
\hline & CM2 & Pseudomonas luteola \\
\hline & CM3 & Pseudomonas oryzihabitans \\
\hline & CM4 & Staphylococcus xylosus \\
\hline \multirow{5}{*}{$\begin{array}{l}\text { Acheta domesticus } \\
\text { (cricket) }\end{array}$} & CM1 & Klebsiella pneumoniae \\
\hline & CM2 & Pantoea spp1 \\
\hline & CM3 & Staphylococcus auricularis \\
\hline & CM4 & Staphylococcus lentus \\
\hline & CM5 & Staphylococcus xylosus \\
\hline \multirow{3}{*}{$\begin{array}{l}\text { Anadara granosa } \\
\text { (blood clam) }\end{array}$} & CM1 & Micrococcus spp \\
\hline & CM2 & Pseudomonas oryzihabitans \\
\hline & $\mathrm{CM} 3$ & Staphylococcus sciuri \\
\hline \multirow{3}{*}{$\begin{array}{l}\text { Blaptica dubia } \\
\text { (dubia roach) }\end{array}$} & CM1 & Staphylococcus hominis \\
\hline & CM2 & Staphylococcus xylosus \\
\hline & CM3 & Staphylococcus xylosus \\
\hline
\end{tabular}


Table 3. The effects of conditioned media of selected invertebrate species on growth and cell death of various human cancer and normal cells.

\begin{tabular}{|c|c|c|c|c|c|c|c|}
\hline \multirow{2}{*}{ Invertebrates } & \multirow{2}{*}{ Bacteria species } & \multicolumn{3}{|c|}{ \% Growth } & \multicolumn{3}{|c|}{ \% Cell Death } \\
\hline & & HeLa & PC3 & HaCaT & HeLa & PC3 & HaCaT \\
\hline Control & & & $100 \%$ & & & $0 \%$ & \\
\hline \multirow{3}{*}{$\begin{array}{l}\text { Scolpendra } \\
\text { subspinipes } \\
\text { (centipede) }\end{array}$} & Kocuria varians & $0 \pm 0$ & $0 \pm 0$ & $0 \pm 0$ & $85.2 \pm 4.0$ & $100 \pm 4.0$ & $100 \pm 4.8$ \\
\hline & Micrococcus spp. & $68.0 \pm 12.2$ & $93.9 \pm 4.7$ & $70.6 \pm 7.4$ & $5.5 \pm 1.1$ & $0.6 \pm 5.4$ & $2.3 \pm 0.7$ \\
\hline & $\begin{array}{l}\text { Staphylococcus } \\
\text { lentus }\end{array}$ & $59.3 \pm 5.4$ & $46.5 \pm 3.0$ & $43.4 \pm 3.4$ & $2.2 \pm 1.3$ & $28.7 \pm 0.6$ & $16.7 \pm 4.8$ \\
\hline \multirow{4}{*}{$\begin{array}{l}\text { Penaeus } \\
\text { monodon } \\
\text { (tiger prawn) }\end{array}$} & $\begin{array}{l}\text { Acinetobacter } \\
\text { baumannii }\end{array}$ & $56.2 \pm 3.3$ & $46.8 \pm 7.1$ & $66.1 \pm 0.4$ & $8.6 \pm 2.3$ & $0 \pm 6.0$ & $76.7 \pm 10.6$ \\
\hline & $\begin{array}{l}\text { Pseudomonas } \\
\text { luteola }\end{array}$ & $67.9 \pm 9.1$ & $47.7 \pm 0.6$ & $52.6 \pm 0.1$ & $9.9 \pm 3.8$ & $0 \pm 2.3$ & $67.8 \pm 12.7$ \\
\hline & $\begin{array}{l}\text { Pseudomonas } \\
\text { oryzihabitans }\end{array}$ & $0 \pm 0.2$ & $0 \pm 0.1$ & $0 \pm 0.5$ & $72.1 \pm 3.7$ & $92.1 \pm 4.0$ & $69.0 \pm 2.2$ \\
\hline & $\begin{array}{l}\text { Staphylococcus } \\
\text { xylosus }\end{array}$ & $56.9 \pm 0.6$ & $80.2 \pm 6.0$ & $42.0 \pm 7.0$ & $10.1 \pm 3.0$ & $5.8 \pm 1.3$ & $20.8 \pm 5.7$ \\
\hline \multirow{5}{*}{$\begin{array}{l}\text { Acheta } \\
\text { domesticus } \\
\text { (cricket) }\end{array}$} & $\begin{array}{l}\text { Klebsiella } \\
\text { pneumoniae }\end{array}$ & $60.2 \pm 3.5$ & $48.1 \pm 0.3$ & $45.8 \pm 2.3$ & $1.5 \pm 0.8$ & $0 \pm 1.1$ & $20 \pm 11.7$ \\
\hline & Pantoea spp. & $72.9 \pm 0.7$ & $67.6 \pm 2.3$ & $75.8 \pm 8.9$ & $3.6 \pm 3.4$ & $0 \pm 1.6$ & $23.7 \pm 7.3$ \\
\hline & $\begin{array}{l}\text { Staphylococcus } \\
\text { auricularis }\end{array}$ & $64.1 \pm 1.4$ & $72.0 \pm 2.8$ & $48.6 \pm 0.4$ & $0.7 \pm 1.9$ & $0 \pm 0.5$ & $2.3 \pm 2.4$ \\
\hline & $\begin{array}{l}\text { Staphylococcus } \\
\text { lentus }\end{array}$ & $55.5 \pm 2.7$ & $64.6 \pm 4.2$ & $56.7 \pm 7.5$ & $1.6 \pm 0.1$ & $0 \pm 0.7$ & $10.5 \pm 6.4$ \\
\hline & $\begin{array}{l}\text { Staphylococcus } \\
\text { xylosus }\end{array}$ & $55.0 \pm 2.0$ & $99.1 \pm 2.4$ & $53.3 \pm 3.5$ & $4.2 \pm 6.0$ & $0 \pm 0.8$ & $0 \pm 7.5$ \\
\hline \multirow{3}{*}{$\begin{array}{l}\text { Anadara } \\
\text { granosa } \\
\text { (blood clam) }\end{array}$} & Micrococcus spp. & $49.1 \pm 2.3$ & $8.0 \pm 3.1$ & $16.3 \pm 3.5$ & $1.0 \pm 0.2$ & $0 \pm 1.8$ & $0.3 \pm 4.6$ \\
\hline & $\begin{array}{l}\text { Pseudomonas } \\
\text { oryzihabitans }\end{array}$ & $62.8 \pm 2.7$ & $11.9 \pm 12.7$ & $0 \pm 12.9$ & $0.7 \pm 0.8$ & $0 \pm 7.3$ & $21.0 \pm 3.3$ \\
\hline & $\begin{array}{l}\text { Staphylococcus } \\
\text { sciuri }\end{array}$ & $55.6 \pm 7.1$ & $96.5 \pm 0.4$ & $48.0 \pm 7.8$ & $8.9 \pm 3.2$ & $0 \pm 5.4$ & $62.8 \pm 2.9$ \\
\hline \multirow{3}{*}{$\begin{array}{l}\text { Blaptica } \\
\text { dubia } \\
\text { (dubia roach) }\end{array}$} & $\begin{array}{l}\text { Staphylococcus } \\
\text { hominis }\end{array}$ & $77.3 \pm 2.1$ & $81.6 \pm 4.0$ & $70.0 \pm 2.5$ & $0.8 \pm 0.7$ & $0 \pm 1.7$ & $0 \pm 0$ \\
\hline & $\begin{array}{l}\text { Staphylococcus } \\
\text { xylosus }\end{array}$ & $65.8 \pm 1.8$ & $49.3 \pm 6.6$ & $73.1 \pm 7.0$ & $2.5 \pm 1.1$ & $0 \pm 0.8$ & $58.9 \pm 0.4$ \\
\hline & $\begin{array}{l}\text { Staphylococcus } \\
\text { xylosus }\end{array}$ & $68.2 \pm 8.0$ & $97.5 \pm 4.3$ & $77.2 \pm 8.5$ & $2 \pm 1.4$ & $0 \pm 1.2$ & $25.9 \pm 2.1$ \\
\hline
\end{tabular}

Similarly, conditioned media of A. baumannii from prawn showed reduced growth against PC3 cells compared with HaCat cells $(\mathrm{P}<0.05)$ (Table 3). For cytotoxicity, conditioned media of P. oryzihabitans from prawn showed higher cytotoxicity against PC3 cells compared with HaCat cells (Table 3). In contrast, conditioned media of $K$. varians exhibited broad-spectrum cytotoxic effects (Table 3), while other lysates showed no or minimal effects. The representative images for $\mathrm{HaCaT}, \mathrm{HeLa}$ and PC3 cells further confirm that CM1, CM2 and CM4 but not CM3 from tiger prawn did not yield any significant cytotoxic effects against cell lines tested (Fig. 2A,B,C). The cells treated with CM3 were observed to be smaller and rounder in shape. Furthermore, the cell staining indicated that cells were not affected post-treatment with CM1, CM2 and CM4 from prawn, similar to the negative controls, indicating that cells were viable, except for cells treated with CM3 (Fig. 2C). 
A)

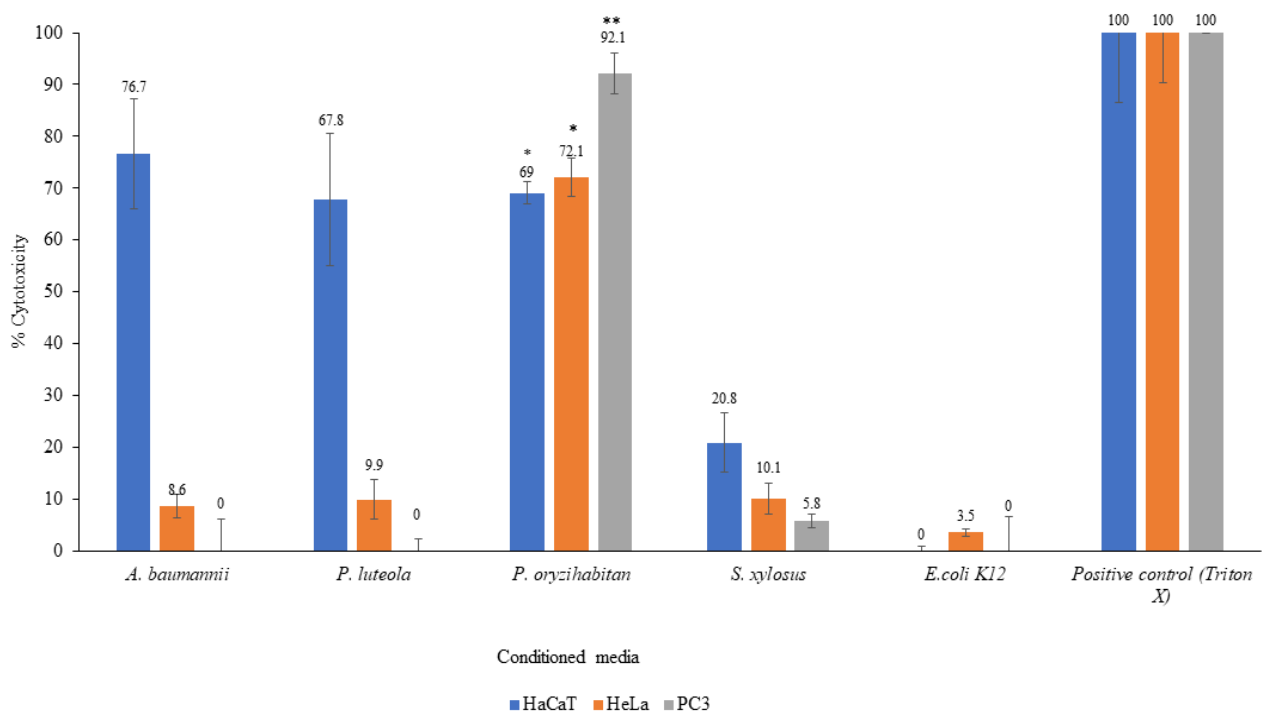

B)
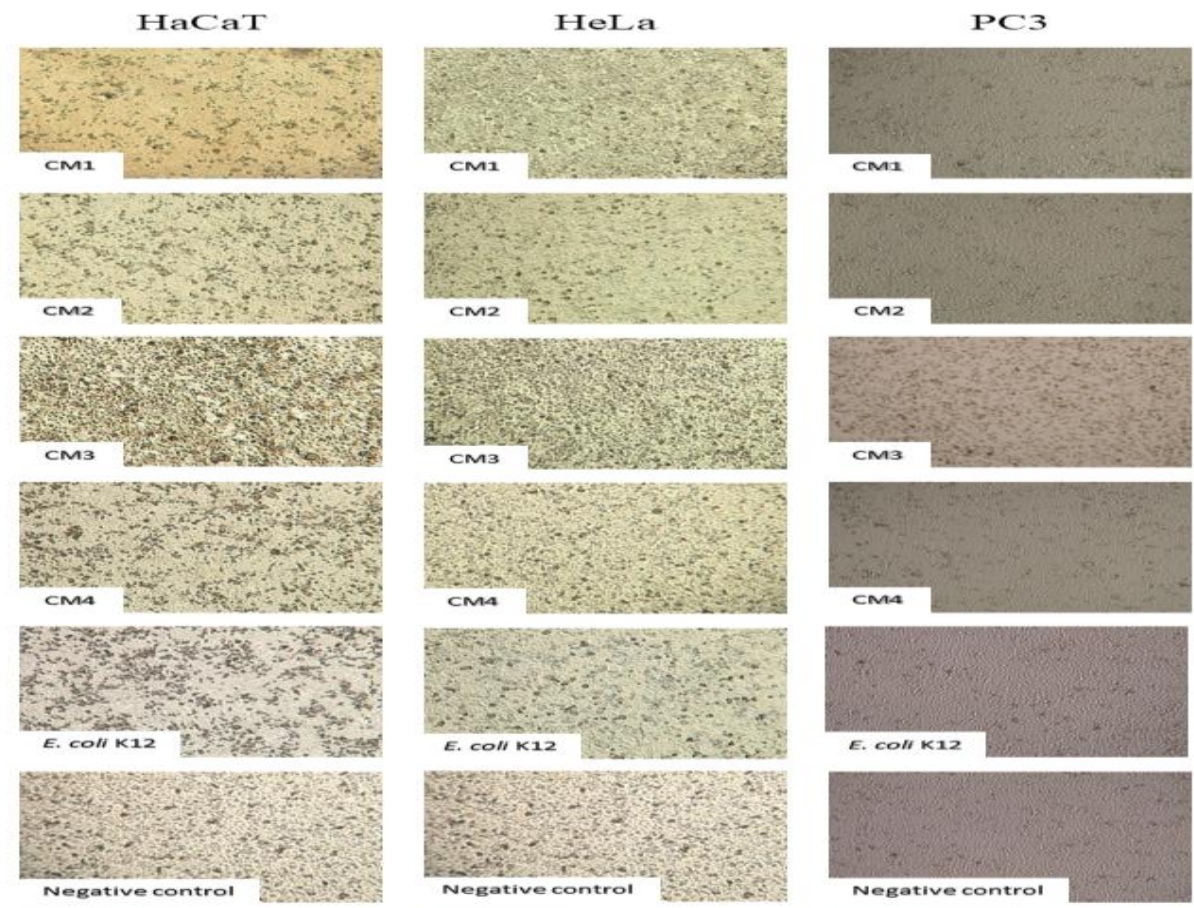

E. coll $\mathrm{k} 12$
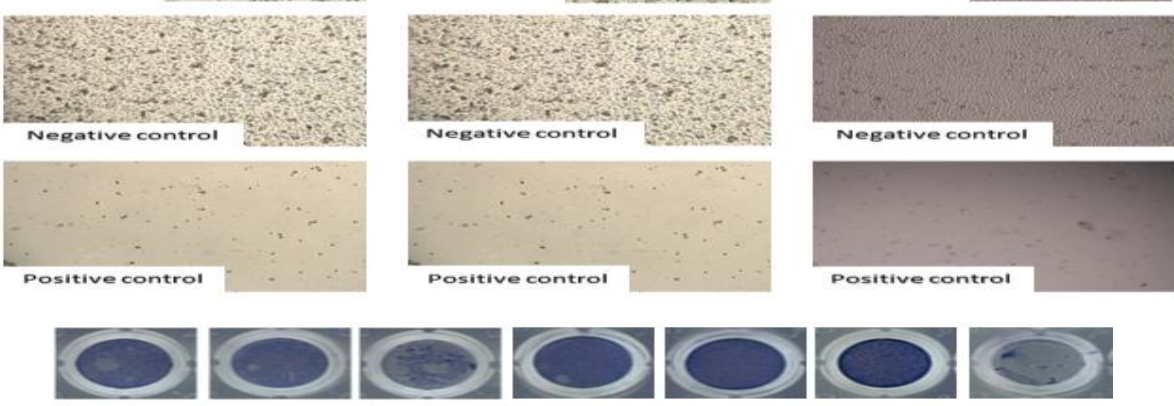

CM1

$\mathrm{CM} 2$

$\mathrm{CM} 3$

CM4

E. coli K12

Negative

Positive
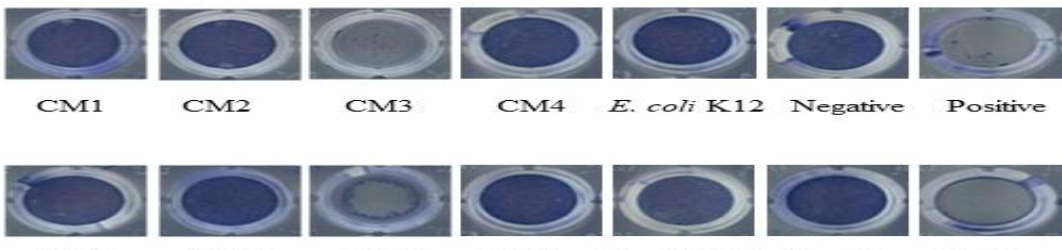

$\mathrm{CM} 3$

Negative

Positive

C)
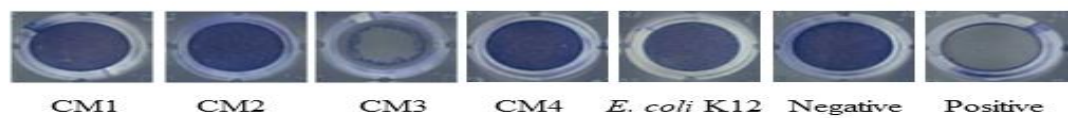

Positive

Figure 2A: The cytotoxic effect of the conditioned media from tiger prawn against HaCaT, HeLa and PC3

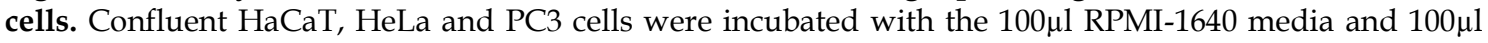


conditioned media prepared by incubating the isolated bacteria into RPMI-1640 media overnight and cytotoxicity was determined as described in Materials and Methods. $P$ values were determined using two sample T- test, two- tailed distribution. The results represent mean \pm standard error of several experiments performed in duplicate. B: Representative images of the cytotoxic effect of tiger prawn conditioned media against HaCaT, HeLa and PC3 cells. For the representative images, an inverted light microscope was used to capture images of the cells in each well at x200 magnification. [CM1: A. baumannii, CM2: P. luteola, CM3: P. oryzihabitans, CM4: S. xylosus, K12: E. coli K12, N: negative and P: positive]. The results are representative of several experiments. C: The trypan blue staining images for the cytotoxic effect of tiger prawn conditioned media against HaCaT, HeLa and PC3 cells. The cells from LDH assays were subjected to fixation using methanol and acetone in a ratio of 1:1, followed by cell viability staining using trypan blue. [CM1: A. baumannii, CM2: P. luteola, CM3: P. oryzihabitans, CM4: S. xylosus, K12: E. coli K12, N: negative and P: positive]. The results are representative of several experiments.

\subsection{Centipede and prawn lysates showed anticancer properties activity against HeLa and HaCaT cells}

Cytotoxicity assays were performed to determine the cytotoxic effects of prawn's lysates against HaCaT, PC3 and HeLa cells. As shown in Table 4, the prawn gut showed 20\% and 8.6\% cytotoxicity against Hela and PC3 cells but no cytotoxic activity against HaCaT cells were observed. These are remarkable findings and clearly show that selected organ lysates possess anticancer molecules. Importantly, centipede showed $30 \%$ and $72 \%$ cytotoxicity against Hela and PC3 cells but no cytotoxic effects were observed against normal HaCat cells (Table 4). The organ lysates showed broad-spectrum anticancer properties (Table 4). In growth inhibition, cricket gut lysates and dubia cockroach inhibited growth of PC3 cells compared with HaCat cells (Table 4).

Table 4. Effects of lysate of selected animals on growth/cell death of human cancer and normal cells.

\begin{tabular}{|c|c|c|c|c|c|c|c|}
\hline \multirow{2}{*}{ Invertebrates } & & \multicolumn{3}{|c|}{ \% Growth } & \multicolumn{3}{|c|}{ \% Cell Death } \\
\hline & & HeLa & PC3 & HaCaT & HeLa & PC3 & HaCaT \\
\hline Control & & & $100 \%$ & & & $0 \%$ & \\
\hline \multirow{5}{*}{$\begin{array}{l}\text { Scolpendra } \\
\text { subspinipes } \\
\text { (centipede) }\end{array}$} & Head & $17.8 \pm 12.1$ & $0 \pm 0$ & $0 \pm 10.6$ & $13 \pm 12.5$ & $69.2 \pm 26.6$ & $45 \pm 27.0$ \\
\hline & $\begin{array}{l}\text { Reproductive } \\
\text { system }\end{array}$ & $35.1 \pm 4.1$ & $0.5 \pm 0.7$ & $21.5 \pm 7.6$ & $1 \pm 1.0$ & $0 \pm 0$ & $19 \pm 18.5$ \\
\hline & Body & $15.6 \pm 13.1$ & $50.4 \pm 2.0$ & $12.0 \pm 39.8$ & $35 \pm 17.0$ & $9.4 \pm 0.7$ & $13 \pm 13.0$ \\
\hline & Egg & $51.6 \pm 0.5$ & $65.2 \pm 0.3$ & $0 \pm 4.0$ & $0 \pm 0$ & $0 \pm 0$ & $0 \pm 0$ \\
\hline & Haemolymph & $0 \pm 1.8$ & $0 \pm 0$ & $0 \pm 8.7$ & $30 \pm 1.0$ & $72.7 \pm 27.3$ & $5 \pm 4.5$ \\
\hline \multirow{6}{*}{$\begin{array}{l}\text { Penaeus } \\
\text { monodon } \\
\text { (tiger prawn) }\end{array}$} & Gut & $15.3 \pm 19.0$ & $0 \pm 0.4$ & $0 \pm 46.3$ & $8.6 \pm 2.3$ & $20.4 \pm 18.9$ & $0 \pm 0$ \\
\hline & Eye & $100 \pm 17.2$ & $100 \pm 3.3$ & $40.3 \pm 12.0$ & $9.9 \pm 3.8$ & $0 \pm 0$ & $0 \pm 0$ \\
\hline & Exoskeleton & $100 \pm 16.5$ & $94.9 \pm 14.1$ & $19.4 \pm 1.4$ & $72.1 \pm 3.7$ & $0 \pm 0$ & $0 \pm 0$ \\
\hline & Body & $61.3 \pm 9.3$ & $70.1 \pm 2.6$ & $33.6 \pm 39.6$ & $57 \pm 6.0$ & $0 \pm 0$ & $48 \pm 16.5$ \\
\hline & Head & $85.2 \pm 14.3$ & $94.8 \pm 11.0$ & $81.5 \pm 15.9$ & $13 \pm 18.4$ & $0.9 \pm 0.9$ & $19 \pm 19.0$ \\
\hline & Appendages & $100 \pm 6.2$ & $82.1 \pm 2.5$ & $100 \pm 64.2$ & $0 \pm 0$ & $11.3 \pm 2.9$ & $20.5 \pm 14.5$ \\
\hline \multirow{3}{*}{$\begin{array}{l}\text { Acheta } \\
\text { domesticus } \\
\text { (cricket) }\end{array}$} & Head & $69.7 \pm 15.1$ & $45.1 \pm 2.3$ & $58.2 \pm 16.7$ & $0 \pm 0$ & $0 \pm 0$ & $0 \pm 0$ \\
\hline & Gut & $63.5 \pm 19.6$ & $22.3 \pm 0.7$ & $45.5 \pm 12.1$ & $28 \pm 16.0$ & $0 \pm 0$ & $10 \pm 10$ \\
\hline & Upper abdomen & $62.4 \pm 1.5$ & $32.2 \pm 5.0$ & $28.6 \pm 14.6$ & $6 \pm 6.0$ & $57 \pm 43$ & $32 \pm 21$ \\
\hline \multirow{3}{*}{$\begin{array}{l}\text { Blaptica dubia } \\
\text { (dubia roach) }\end{array}$} & Egg & $62.5 \pm 2.6$ & $50.1 \pm 4.1$ & $74.8 \pm 21.2$ & $18.0 \pm 4.5$ & $0 \pm 0$ & $0 \pm 0$ \\
\hline & Gut & $100 \pm 3.4$ & $100 \pm 15.2$ & $33.5 \pm 18.9$ & $0 \pm 0$ & $0 \pm 0$ & $6 \pm 5.5$ \\
\hline & Upper abdomen & $79.3 \pm 2.4$ & $47.1 \pm 4.5$ & $42.7 \pm 14.9$ & $0 \pm 0$ & $0 \pm 0$ & $0 \pm 0$ \\
\hline
\end{tabular}

\section{DISCUSSION}

This study focuses on identifying potential anticancer agents in selected invertebrates and their gut microbiota. Several invertebrates were selected due to the natural polluted habitats as shown in Table 1. Although, recent studies have tested human gut microbiota for anticancer agents [14,15], to our knowledge, this is the first study to mine gut bacteria of selected invertebrates for potential anticancer molecules. Zhou et al., [15] revealed the anticancer activity of gut bacteria isolated from the fecal sample of a group of healthy individuals; preschool children and university students. If bacteria isolated from humans can possess anticancer properties, it is logical to speculate that pests that thrive in polluted environments and are able to withstand high levels of radiation may contribute to the resistance of cancer development in the host species $[13,16]$. Notably, Homo sapiens are just one species among millions of other species and we are a relatively new 
addition to this planet. Other species such as cockroaches, crocodile/alligator have shown the ability to adapt, evolve and survive successfully over millions of years, suggesting that we ought to learn from these species $[12,13]$. Besides their immunity, their gut microbiota likely contribute to their protection against communicable and non-communicable diseases by secretion of antimicrobial and anticancer agents respectively. In this regard, the microbial world has attracted increasing attention due to its' ability to thrive in different environments by synthesizing bioactive molecules. The by-products synthesized by bacteria are becoming more valuable in the medicinal field. Studies have been conducted to examine the anti-cancer properties of microorganisms isolated from various environments; water, plant extracts, soil and clinical samples. Phonnok et al., [17] reported the anti-cancer activity of a spectrum of bacteria including A. baumannii, Pseudomonas aeruginosa and Bacillus sp., which exhibited cytotoxic effect against HeLa cervical cancer cells leaving normal cell line (Vero) unaffected. The study also indicated that the extracts of those bacterial species inhibited the growth of HeLa cells without having any significant effect on the normal cells [17]. The anticancer activity of five strains of soil microorganisms isolated from Tangkuban Perahu mountain against T47D breast cancer cell line were demonstrated. Our findings are consistent with these studies and clearly showed that bacteria isolated from novel sources such as polluted environments are potential sources of anticancer molecule(s).

In this study, conditioned media of the invertebrates' aerobic gut microbiota were prepared and tested for anticancer activity. The results revealed that $\mathrm{CM} 3$ from tiger prawn corresponding to $P$. oryzihabitanss and CM1 from centipede corresponding to $K$. varians exhibited cytotoxic effects and growth inhibitory effects against both HeLa and PC3 cells. However, the identity of the active molecules remains unknown and it is the subject of future studies. Of interest, Karpiński and Szkaradkiewicz [18] identified several anticancer peptides from bacteria including azurin, a $14 \mathrm{kDa}$ peptide synthesized by Pseudomonas that was shown to trigger apoptosis in tumor cells by inducing the activation of the caspase cascade [19]. Beside from forcing cells to undergo apoptosis, this peptide exhibited penetration into tumor cells compared with the heathy cells. Moreover, antibacterials such as actinomycin D, bleomycin, doxorubicin and mitomycin C synthesized by bacteria exhibited anticancer properties [20]. The anticancer mechanisms of each of these molecules are however different from each other. While actinomycin D triggers p53-independent apoptosis in cells [21] and bleomycin exhibit oxygen and metal ion-dependent cleavage of the DNA [22]. Doxorubicin, in turn, inhibits DNA and RNA replication and transcription and causes oxidative stress in tumor cells, triggering membrane, protein and DNA damage [23]. Similar mechanisms may explain our findings. In conclusion, these results show that the gut microbiota of selected invertebrates produce molecules with anticancer properties. Thus, these molecules could potentially be used as drug leads for the rational development of therapeutic agents against cancer cells, however, intensive research over the next few decades is needed to realize these expectations.

This study also shows that cherry red centipede organ extracts and serum, tiger prawn organ extracts, and house cricket organ extracts affect the viability of cancerous cell lines, HeLa and PC3. This novel finding is highly significant as it may lead to the identification of novel compounds that may be able to target and destroy cancer cells. Although the actual molecules that act against cancer cells and their mechanism of actions are yet to be determined, it is obvious that tiger prawn body and gut, cherry red centipede head, body, reproductive system, egg and haemolymph, and house cricket upper abdomen and gut are the organ extracts that contain molecules that can act against cancer cells.

Our results are consistent with previous studies such as a report where it was shown that compounds from Penaeus latisculatus (king prawn) showed anticancer activity [24] and another report where it was shown that red cherry centipede lysates exhibited anti-cancer activity when tested in mice infected with S180 sarcoma and H22 hepatoma [25]. Interestingly, lysates such as the tiger prawn head and gut, cherry red centipede haemolymph, and house cricket gut showed cytotoxic effect against cancer cells but had negligible or no cytotoxic activity against normal cells

\section{CONCLUSIONS}

In conclusion, we showed that the organ lysates and gut bacteria of selected invertebrates residing in polluted environments exhibit potent anti-tumour activity. These findings further suggest that animals residing in polluted milieus are a large unexploited source for prospective pharmaceutical drugs that may lead to the identification of novel anti-tumour compound(s) and/or understanding of the mechanisms of cancer resistance in such species, however extensive research over the next few years is needed to realize these expectations. 


\section{MATERIALS AND METHODS}

\subsection{Dissection}

Acheta domesticus (cricket), Anadara granosa (blood clam), Blaptica dubia (cockroach), Penaeus monodon (tiger prawn) and Scolpendra subspinipes (centipede) were procured (Table 1). Various organs were extracted, and samples collected as described previously $[12,13,26,27]$ (also shown in Fig. 1). All the organs were kept on ice during the dissection. Once extracted, the organs were homogenized in the presence of protease inhibitors and EDTA. Next, lysates were freeze-thawed ten times and sonicated at $30 \mathrm{GHz}$. The samples were then centrifuged at $15000 \times \mathrm{g}$ for $80 \mathrm{~min}$ at $4^{\circ} \mathrm{C}$. The supernatants, known as lysates, were collected and filtered using filters of $0.2 \mu \mathrm{M} 0.2$ pore-size and stored at $-80^{\circ} \mathrm{C}$ (Siddiqui et al., 2017). The Bradford assay was used to determine the concentration of protein in the lysates and tested for against human cancer and normal cells.

To isolate gut bacteria of invertebrate species, A. granosa shell was opened using a pair of scissors, and the middle section of the invertebrate was dissected to expose the gut. Next, bacteria were isolated from the gut using a sterile cotton swab and streaked on blood agar as well as nutrient agar plates. For $A$. domesticus, $B$. dubia, P. monodon and S. subspinipes, invertebrates were deactivated by incubating on ice for $5 \mathrm{~min}$ and the dissection was carried out as described above. The agar plates were then incubated overnight at $37{ }^{\circ} \mathrm{C}$ (Akbar et al., 2018). Following the incubation, bacterial colonies were isolated based on their texture, size, color and shape onto fresh blood and nutrient agar plates. The bacterial colonies were then subjected to identification through Analytical profile index (API) [26,27].

\subsection{Analytical profile index (API) identification}

Prior to API identification, Gram staining was conducted. API staph was used for the identification of Gram-positive and catalase positive bacteria, while API 20E was used for Gram-negative and oxidase negative bacteria. API identification was conducted by inoculating the bacterial species into the respective API followed by 18 to $24 \mathrm{~h}$ incubation at $37^{\circ} \mathrm{C}$. After incubation, additional tests were conducted, and the results were recorded to determine the identity of the bacteria.

\subsection{Preparation of bacterial conditioned medium}

Conditioned media were prepared by inoculating single colonies of bacteria in RPMI-1640 medium, followed by $24 \mathrm{~h}$ incubation at $37^{\circ} \mathrm{C}$ in an aerobic environment with shaking. The cultures were subjected to centrifugation at $4^{\circ} \mathrm{C}, 12,000 \mathrm{xg}$, for $1 \mathrm{~h}$. Next, the supernatants were collected and filtered using a $0.22 \mu \mathrm{m}$ pore size syringe filter. The conditioned media were then stored at $-80^{\circ} \mathrm{C}[26,27]$. Bradford assay was conducted to determine the protein concentration of the conditioned media.

\subsection{Cell cultures}

Cancer cell lines; HeLa (ATCC® CCL2 ${ }^{\mathrm{TM}}$ ) and PC3 (ATCC® CRL1435 ${ }^{\mathrm{TM}}$ ) and normal cell line; HaCaT; acquired from American Type of Culture Collection, were used in this study. All the cell lines were cultured in RPMI-1640 supplemented with 10\% fetal bovine serum (FBS), 1\% L-glutamine, 1\% penicillin streptomycin antibiotic and $1 \%$ Minimum Essential Media (MEM) Non-Essential amino acid at $37^{\circ} \mathrm{C}$, with a supply of $5 \%$ carbon dioxide and $95 \%$ humidity $[12,13]$.

\subsection{Cytotoxicity assays}

Lactate dehydrogenase (LDH) assay was initiated by seeding the cells (HaCaT, HeLa and PC3) and incubated at $37^{\circ} \mathrm{C}$ with $5 \% \mathrm{CO}_{2}$ and $95 \%$ humidity. $\mathrm{LDH}$ was conducted using confluent cell monolayers as described previously (Siddiqui et al., 2017; Akbar et al., 2018). Briefly, cells were incubated with organ lysates, conditioned media and RPMI-1640 media for $24 \mathrm{~h}$ at $37^{\circ} \mathrm{C}$ with $5 \% \mathrm{CO}_{2}$ and $95 \%$ humidity. After incubation, the supernatants were collected and the percentage cytotoxicity was calculated as follows: $\%$ cytotoxicity = $\left(\left(\right.\right.$ Absorbance $_{\text {sample }}-$ Absorbance $\left._{\text {negative control }}\right) /\left(\right.$ Absorbance $_{\text {positive control }}-$ Absorbance $\left._{\text {negative control })}\right)$ *100, whereby the negative control consist of cells treated with conditioned media from non-pathogenic E. coli K-12 bacteria and RPMI-1640 media only, while the positive control consisted of cells treated with Triton $x-100$

This assay is based on measuring lactate dehydrogenase (LDH) release; a soluble cytosolic enzyme, found in all cells, released into the culture medium by damaged cells only. The principle of this assay is that cell supernatant containing LDH catalyses the conversion of lactate (solution from kit) to pyruvate, generating $\mathrm{NADH}$ and $\mathrm{H}+$. In the second step, the catalyst (diaphorase, solution from kit) transfers $\mathrm{H}$ and $\mathrm{H}+$ from $\mathrm{NADH}$ and $\mathrm{H}+$ to the tetrazolium salt p-iodo-nitrotetrazolium violet (INT), which is reduced to formazon (dye), and absorbance is read at $492 \mathrm{~nm}$. The cells incubated alone were used as negative controls, whereas monolayers 
lysed with $1 \%$ Triton $\mathrm{X}-100$ for $30 \mathrm{~min}$ at $37^{\circ} \mathrm{C}$ were used as $100 \%$ cell death. Control values were acquired from cells incubated alone and total LDH release was measured from cells treated with 5\% Triton X-100 for 1 $\mathrm{h}$ at $37^{\circ} \mathrm{C}$. To further determine the viability of treated cells, survival assays were performed. Briefly, cells treated with lysates and conditioned media were collected and seeded onto new plates containing growth media.

\subsection{Growth inhibition assays}

Assays were performed to determine the effects of organ lysate(s) and conditioned media on cell growth. Briefly, cancer cells and normal cells were inoculated in 96-well plates for $24 \mathrm{~h}$ at $37^{\circ} \mathrm{C}$ in a $5 \% \mathrm{CO} 2$ incubator until a semi-confluent monolayer (up to $50 \%$ confluency) was formed. At this stage, cells were trypsinized and cell count was determined using a haemocytometer. Next, organ lysates and conditioned media were added to the semi-confluent monolayer of cells and plates were incubated for $24 \mathrm{~h}$ at $37^{\circ} \mathrm{C}$ in a $5 \%$ $\mathrm{CO} 2$ incubator. For controls, cells were incubated with complete growth medium and/or BSA. Following this incubation, the cells were trypsinized with $2.5 \%$ trypsin for $15 \mathrm{~min}$ and enumerated using a haemocytometer.

\subsection{Statistical analysis}

Statistical significance for differences was evaluated using a 2-sample t-test; two-tailed distribution, comparing the mean of two different experiments repeated using similar conditions. $P$ values $<0.5,<0.1$ and $<0.05$ were used for analysis. For graphical representation of the data, $y$-axis error indicated the standard error of the data between the repeats on the figure.

Acknowledgements: Authors acknowledge Sunway University, Malaysia, grant FST-2017-03 for financial support.

Author contributions: Concept - R.S., N.A.K.; Design - R.S., M.S., M.M.; Supervision - R.S., N.A.K., K.S.; Materials R.S., K.S.; Data Collection and/or Processing - M.S., M.M.; Analysis and/or Interpretation - M.S., M.M.; Literature Search - M.S., M.M.; Writing - M.S., M.M., R.S.; Critical Reviews - R.S., N.A.K., K.S., M.S., M.M.

Conflict of interest statement: The authors declared no conflict of interest.

\section{REFERENCES}

[1] Ferlay J, Soerjomataram I, Dikshit R, Eser S, Mathers C, Rebelo M, Parkin DM, Forman D, Bray F. Cancer incidence and mortality worldwide: sources, methods and major patterns in GLOBOCAN 2012. Int J Can. 2015; 136: 359-386. [CrossRef]

[2] Torre LA, Bray F, Siegel RL, Ferlay J, Lortet- Tieulent J, Jemal A. Global cancer statistics, 2012. CA-Cancer J Clin. 2015; 65: 87-108. [CrossRef]

[3] Block KI, Gyllenhaal C, Lowe L, Amedei A, Amin ARMR, Amin A, Aquilano K, Arbiser J, Arreola A, Arzumanyan A, Ashraf SS, Azmi AS, Benencia F, Bhakta D, Bilsland A, Bishayee A, Blain SW, Block PB, Boosani CS, Carey TE, Carnero A, Carotenuto M, Casey SC, Chakrabarti M, Chaturvedi R, Chen GZ, Chen H, Chen S, Chen YC, Choi BK, Ciriolo MR, Coley HM, Collins AR, Connell M, Crawford S, Curran CS, Dabrosin C, Damia G, Dasgupta S, DeBerardinis RJ, Decker WK, Dhawan P, Diehl AME, Dong JT, Dou QP, Drew JE, Elkord E, El-Rayes B, Feitelson MA, Felsher DW, Ferguson LR, Fimognari C, Firestone GL, Frezza C, Fujii H, Fuster MM, Generali D, Georgakilas AG, Gieseler F, Gilbertson M, Green MF, Grue B, Guha G, Halicka D, Helferich WG, Heneberg P, Hentosh P, Hirschey MD, Hofseth LJ, Holcombe RF, Honoki K, Hsu HY, Huang GS, Jensen LD, Jiang WG, Jones LW, Karpowicz PA, Keith WN, Kerkar SP, Khan GN, Khatami M, Ko YH, Kucuk O, Kulathinal RJ, Kumar NB, Kwon BS, Le A, Lea MA, Lee HY, Lichtor T, Lin LT, Locasale JW, Lokeshwar BL, Longo VD, Lyssiotis CA, MacKenzie KL, Malhotra M, Marino M, Martinez-Chantar ML, Matheu A, Maxwell C, McDonnell E, Meeker AK, Mehrmohamadi M, Mehta K, Michelotti GA, Mohammad RM, Mohammed SI, Morre DJ, Muralidhar V, Muqbil I, Murphy MP, Nagaraju GP, Nahta R, Niccolai E, Nowsheen S, Panis C, Pantano F, Parslow VR, Pawelec G, Pedersen PL, Poore B, Poudyal D, Prakash S, Prince M, Raffaghello L, Rathmell JC, Rathmell WK, Ray SK, Reichrath J, Rezazadeh S, Ribatti D, Ricciardiello L, Robey RB, Rodier F, Rupasinghe HPV, Russo GL, Ryan EP, Samadi AK, Sanchez-Garcia I, Sanders AJ, Santini D, Sarkar M, Sasada T, Saxena NK, Shackelford RE, Shantha Kumara HMC, Sharma D, Shin DM, Sidransky D, Siegelin MD, Signori E, Singh N, Sivanand S, Sliva D, Smythe C, Spagnuolo C, Stafforini DM, Stagg J, Subbarayan PR, Sundin T, Talib WH, Thompson SK, Tran PT, Ungefroren H, Vander Heiden MG, Venkateswaran V, Vinay DS, Vlachostergios PJ, Wang Z, Wellen KE, Whelan RL, Yang ES, Yang H, Yang X, Yaswen P, Yedjou C, Yin X, Zhu J, Zollo M. Designing a broad-spectrum integrative approach for cancer prevention and treatment. Semin Cancer Biol. 2015; 35 Suppl(Suppl), S276-S304. [CrossRef] 
[4] Palumbo MO, Kavan P, Miller WH Jr, Panasci L, Assouline S, Johnson N, Cohen V, Patenaude F, Pollak M, Jagoe RT, Batist G. Systemic cancer therapy: achievements and challenges that lie ahead. Front Pharmacol. 2013; 4; 57. [CrossRef]

[5] van Zoggel H, Carpentier G, Dos Santos C, Hamma-Kourbali Y, Courty J, Amiche M, Delbé J. Antitumor and angiostatic activities of the antimicrobial peptide dermaseptin B2. PloS One. 2012; 7(9), e44351. [CrossRef]

[6] Lechner M, Russell S, Bass R, Epstein A. Chemokines, costimulatory molecules and fusion proteins for the immunotherapy of solid tumors. Immunotherapy. 2011;3(11): 1317-1340. [CrossRef]

[7] Schneider L, Peleja RP, Kluczkovski A, Freire GM, Marioni B, Vogt PC, Da Silveira R. Mercury concentration in the spectacled caiman and black caiman (Alligatoridae) of the Amazon: implications for human health. Arch Environ Con Tox. 2012; 63: 270-279. [CrossRef]

[8] Rainwater TR, Millichamp NJ, Barrantes ID, Barr BR, Montero JR, Platt SG, Abel MT, Cobb GP, Anderson TA. Ocular disease in American crocodiles (Crocodylus acutus) in Costa Rica. J Wildlife Dis. 2011; 47: 415-426. [CrossRef]

[9] Vieira LM, Nunes Vda S, Amaral MC, Oliveira AC, Hauser-Davis RA, Campos RC. Mercury and methyl mercury ratios in caimans (Caiman crocodilus yacare) from the Pantanal area Brazil. J Environ Monitor. 2010; 13: 280-287. [CrossRef]

[10] Campbell JW, Waters MN, Tarter A, Jackson J. Heavy metal and selenium concentrations in liver tissue from wild American alligator (Alligator mississippiensis) livers near Charleston, South Carolina. J Wildlife Dis. 2010; 46: 123441. [CrossRef]

[11] Janke A, Gullberg A, Hughes S, Aggarwal RK, Arnason U (2005) Mitogenomic analyses place the gharial (Gavialis gangeticus) on the crocodile tree and provide pre-K/T divergence times for most crocodilians. J Mol Evol. 2010; 61: 620-626. [CrossRef]

[12] Siddiqui R, Mansur Ali S, Khan N. Do crocodiles and alligators hold the key to treat cancer? BMJ. 2016 ; 354 : i3763. [CrossRef]

[13] Siddiqui R, Jeyamogan S, Ali SM, Abbas F, Sagathevan K A, Khan NA. Crocodiles and alligators: Antiamoebic and antitumor compounds of crocodiles. Exp Parasitol. 2017; 183: 194-200. [CrossRef]

[14] Louis P, Hold GL, Flint HJ. The gut microbiota, bacterial metabolites and colorectal cancer. Nature Reviews Microbiology. 2014; 12(10): 661-672. [CrossRef]

[15] Zhou YJ, Zhao DD, Liu H, Chen HT, Li JJ, Mu XQ, Liu Z, Li X, Tang L, Zhao ZY, Wu JH, Cai YX, Huang YZ, Wang PG, Jia YY, Liang PQ, Peng X, Chen SY, Yue ZL, Yuan XY, Lu T, Yao BQ, Li YG, Liu GR, Liu SL. Cancer killers in the human gut microbiota: diverse phylogeny and broad spectra. Oncotarget. 2017; 8(30): 49574-49591. [CrossRef]

[16] Berlanga M, Llorens C, Comas J, Guerrero R. Gut Bacterial Community of the Xylophagous Cockroaches Cryptocercus punctulatus and Parasphaeria boleiriana. PloS One. 2016; 11(4): e0152400. [CrossRef]

[17] Phonnok S, Uthaisang-Tanechpongtamb W, Wongsatayanon BT. Anticancer and apoptosis-inducing activities of microbial metabolites. Electron J Biotechn. 2010; 13(5). [CrossRef]

[18] Karpinski TM, Szkaradkiewicz AK. Anticancer peptides from bacteria. Bangladesh J Pharmacol. 2013; 8: 343-348. [CrossRef]

[19] Punj V, Bhattacharyya S, Saint-Dic D, Vasu C, Cunningham EA, Graves J, Yamada T, Constantinou AI, Christov K, White B, Li G. Bacterial cupredoxin azurin as an inducer of apoptosis and regression in human breast cancer. Oncogene. 2004; 23: 2367-2378. [CrossRef]

[20] Karpinski TM, Adamczak. Anticancer Activity of Bacterial Proteins and Peptides. Pharmaceutics. 2018; 10(2) E54 [CrossRef]

[21] Farhane Z, Bonnier F, Byrne HJ. An in vitro study of the interaction of the chemotherapeutic drug Actinomycin D with lung cancer cell lines using Raman micro-spectroscopy. J Biophotonics. 2018; 11(1): e201700112. [CrossRef]

[22] Segerman ZJ, Roy B, Hecht, SM. Characterization of bleomycin-mediated cleavage of a hairpin DNA library. Biochemistry. 2013; 52(31): 5315-5327. [CrossRef]

[23] Cagel M, Grotz E, Bernabeu E, Moretton MA, Chiappetta DA. Doxorubicin: Nanotechnological overviews from bench to bedside. Drug Discov Today. 2017; 22: 270-281. [CrossRef]

[24] Amrollah A, Gholamreza H, Mehdi F. Anticancer effects of HESA-A: An herbal marine compound. Chin J Integr Med. 2010; 16(4): 366-367. [CrossRef] 
[25] Zhao H, Li Y, Wang Y, Zhang J, Ouyang X, Peng R, Yang J. Antitumor and immunostimulatory activity of a polysaccharide-protein complex from Scolopendra subspinipes mutilans L. Koch in tumor-bearing mice. Food Chem Toxicol. 2012; 50(8): 2648-2655. [CrossRef]

[26] Akbar N, Siddiqui R, Iqbal M, Sagathevan K, Khan NA. Gut bacteria of cockroaches are a potential source of antibacterial compound(s). Lett Appl Microbiol. 2018; 66(5): 416-426. [CrossRef]

[27] Ali SM, Siddiqui R, Ong SK, Shah MR, Anwar A, Heard PJ, Khan NA. Identification and characterization of antibacterial compound(s) of cockroaches (Periplaneta americana). Appl Microbiol Biot. 2017; 101(1): $253-286$. [CrossRef]

This is an open access article which is publicly available on our journal's website under Institutional Repository at http://dspace.marmara.edu.tr. 